\title{
Lithic assemblages of Azokh Cave (Nagorno Karabagh, Lesser Caucasus): Raw materials, technology and regional context
}

\author{
Lena Asryan ${ }^{1,2,3}$, Andreu Ollé ${ }^{2,1}$, Norah Moloney ${ }^{4}$ and Tania King ${ }^{5,6}$
}

1. Àrea de Prehistòria, Universitat Rovira i Virgili (URV). Avinguda de Catalunya 35, 43002 Tarragona, Spain. Email: lenaprehistoria@gmail.com

2. IPHES, Institut Català de Paleoecologia Humana i Evolució Social. C/Marcel.lí Domingo s/n (Edifici W3),

Campus Sescelades, 43007, Tarragona, Spain. Email: aolle@iphes.cat

3. Artsakh State University. M. Gosh 5, Stepanakert, Nagorno Karabagh.

4. University College London, Institute of Archaeology, 31-34 Gordon Square, WH1E OPY, London, UK.

Email: tcfa305@ucl.ac.uk

5. Blandford Town Museum. Bere's Yard, Blandford, Dorset, UK. Email: taniacking@gmail.com

6. Institute of Molecular Biology of Armenia. National Academy of Sciences, Yerevan, Armenia.

\begin{abstract}
:
Azokh Cave is a Middle Pleistocene to Holocene site located in Nagorno Karabagh (Lesser Caucasus). The main entrance, Azokh 1, is a large cave that has two geological sequences (lower and upper) with nine geo-archaeological units of which only the upper ones (Units I to V) have a significant archaeological record. The faunal remains and lithic artefacts in these units indicate aspects of human occupation, and exploitation of, and association with animals.

The lithic artefacts presented here were recovered from Units V, III and II during the $2002-$ 2009 excavation seasons. The available chronological data indicates an age between $293-100 \mathrm{Ka}$ for these units. The operational chain is incomplete and artefacts found in the cave are primarily endproducts dominated by flake-tools. The assemblage of Unit V is composed primarily of simple, unretouched flakes with a minimal presence of retouched flakes and cores. The Unit II lithic assemblage includes a substantial Levallois component, although with fewer cores and retouched flakes. There are very few flake tools in Unit III. While it is still difficult to assign the Unit V assemblage to a techno-typological group or complex (i.e. Acheulean, Mousterian or other local techno-complexes such as the Kudarian), the Unit II assemblage is clearly associated with Mode 3 or the Mousterian techno-complex.

Different local and non-local raw materials were exploited in all units for the production of lithic artefacts, although the range of raw materials is more varied in Unit II. Local chert, flint and basalt were used most commonly, probably due to their easy accessibility. Limestone, jasper and sandstone, from local and non-local sources, are present in small quantities in Units V and II. Obsidian is the only raw material that possibly originates from more distant sources. Flint and chert appear to have been preferentially exploited for flake tool production in all units, but the toolmakers show a preference for better quality raw material (flint, basalt, obsidian) for retouched pieces in Units V and II, and for Levallois production in Unit II.
\end{abstract}

Journal of Lithic Studies (2014) vol.1, nr. 1, p. 33-54

doi:10.2218/jls.v1i1.775

Published by the School of History, Classics and Archaeology, University of Edinburgh ISSN: 2055-0472. URL: http://journals.ed.ac.uk/lithicstudies/

This work is licensed under a Creative Commons Attribution 2.5 UK: Scotland License. 
Keywords: Azokh Cave; Middle to Upper Pleistocene; lithic artefacts; raw materials

\section{Introduction}

The Caucasus is a mountainous region that stretches between the Black Sea in the West and the Caspian Sea in the East. The Greater Caucasus, the main and largest mountain range, includes the south-western part of Russia and northern parts of Georgia and Azerbaijan. The Lesser Caucasus runs parallel to the Greater Caucasus and delimits the Armenian Highland. Located as it is in the middle of the African, Asian and European continents, the Caucasus region represents a geographic corridor for the expansion and migration of human and animal populations, although the high mountains and difficult passes of the region might have limited human mobility and expansion in this territory. Hominin presence in the Caucasus is attested by the rich paleontological, anthropological and cultural remains found throughout the Early to Upper Pleistocene and evidenced by Dmanisi (Georgia) dated to 1.7 Myr ago (Gabunia et al. 2001, Adler \& Toushabramishvili 2004, Meignen \& Tushabramishvili 2006) and by other Middle and Upper Palaeolithic sites such as Tsona, Kudaro I and III in South Ossetia, Myshtulagty Lagat in North Ossetia, Djruchula, Bronze Cave, Sakajia, Ortvala and Ortvale Klde in Georgia, Mezmaiskaya, Barakaevskaya and Monasheskaya in NW Caucasus (Golovanova et al. 1999, Golovanova \& Doronichev 2003, Adler et al. 2006, Pinhasi et al. 2008, Golovanova et al. 2010, Pinhasi et al. 2011, Bar-Oz et al. 2012), Dashtadem-3, Hovq 1, Kalavan-2 in northern Armenia (Gasparyan 2010, Ghukasyan et al. 2011, Kolpakov 2009, Pinhasi et al. 2008, 2011), Yerevan-1 and Lusakert-1 and 2 in Hrazdan valley (Eritsian 1981, Ghukastan et al. 2011, Adler et al. 2012) and Angeghakot 1 in southern Armenia (Liagre et al. 2006) (Figure 1).

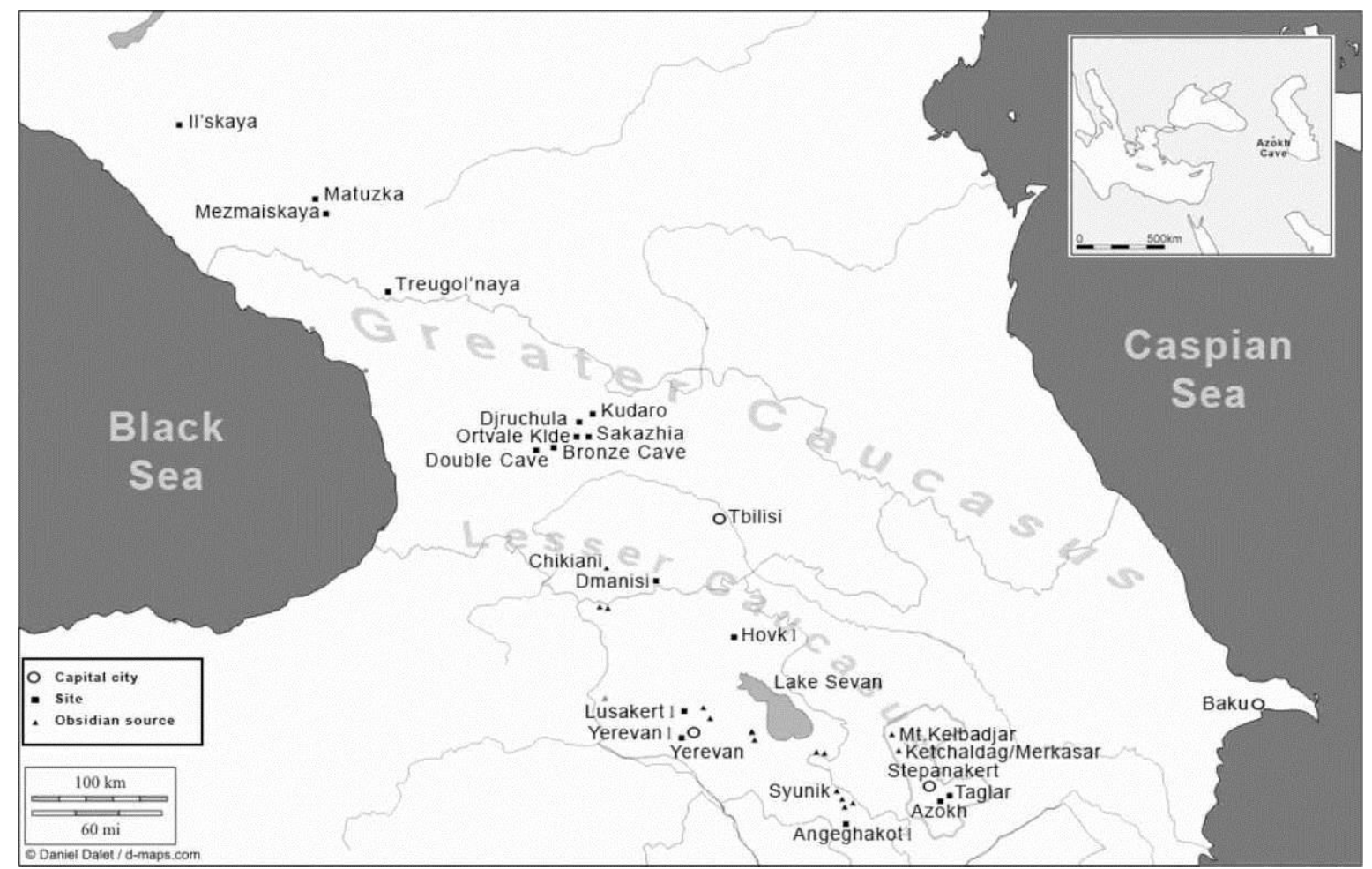

Figure 1. Map of the Caucasus showing the location of Middle to Upper Pleistocene sites and the closest obsidian sources to these sites.

In this paper we discuss the Azokh Cave site located in the south-eastern part of the Lesser Caucasus in Nagorno Karabakh (39 $37.15 \mathrm{~N}$ and $46^{\circ}$ 59.32E) (Murray et al. in press). 
The cave is about $850 \mathrm{~m}$ a.s.1., and $200 \mathrm{~m}$ above the nearby village of Azokh. The main chamber - Azokh 1 - has provided evidence of repeated occupation by human groups during the Middle and Late Pleistocene. Today, Azokh 1 is a large cave 40m long and $11-11.5 \mathrm{~m}$ high, and is one of a number of southwest-facing, fossiliferous chambers which form part of a larger limestone karstic system (Murray et al. 2010) (Figure 2). Almost all units of Azokh 1 Cave show evidence of human involvement (Fernández-Jalvo et al. 2010).
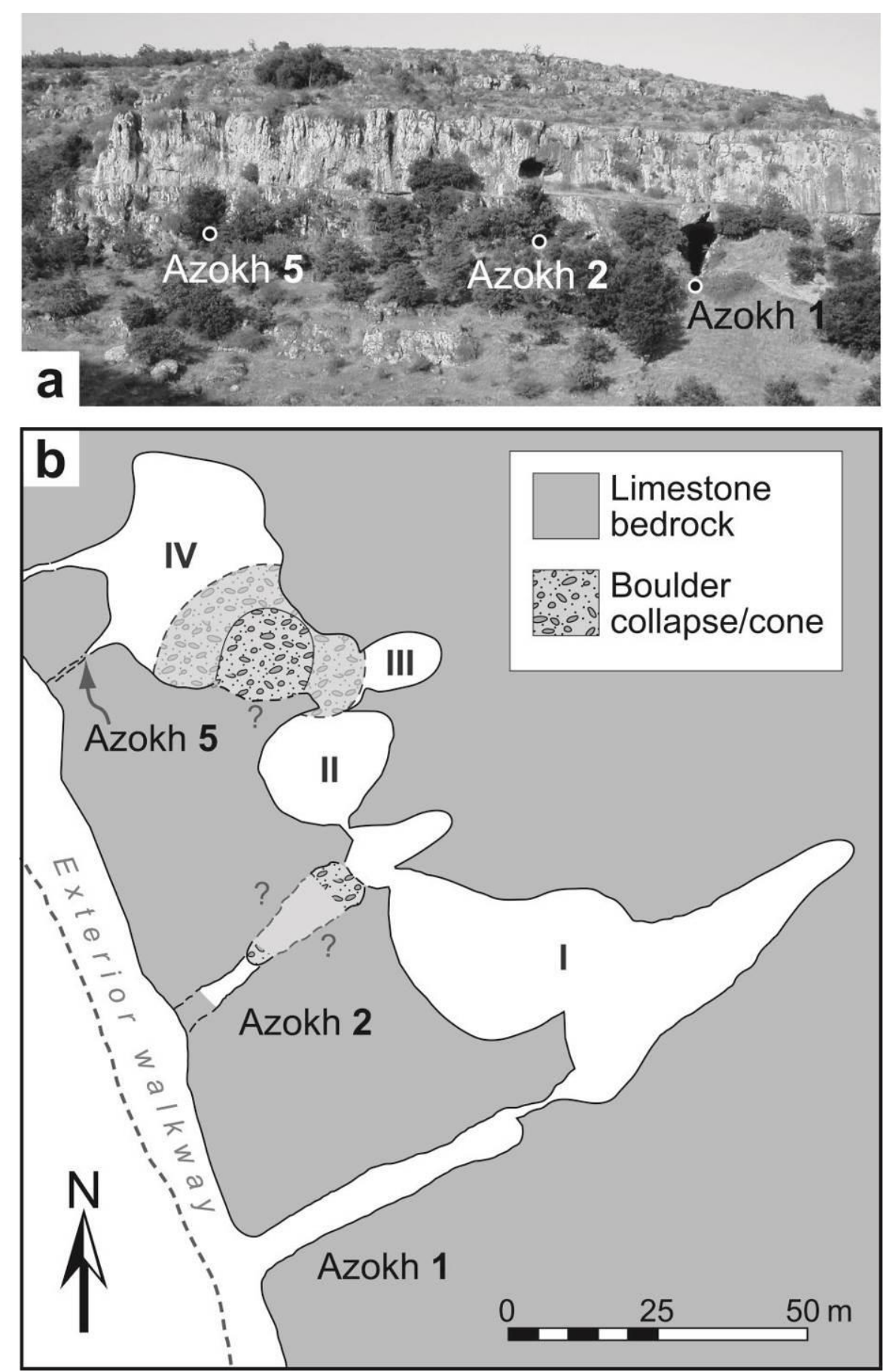

Figure 2. Azokh Cave system: a) View of exterior of cave system, showing three main entrance passages (Azokh 1, 2 and 5) leading to the inner galleries; b) Plan of Azokh Cave system showing the main entrances and internal galleries (Murray et al. 2010, Murray et al. in press). 


\subsection{Historical background}

Azokh cave was discovered by M.M. Guseinov in the late 1950s (Guseinov 1985). Excavations, by a combined Azerbaijan-Russian team under Guseinov's direction, were concentrated mainly in the largest entrance of the cave currently known as Azokh 1, and continued for more than 20 years. A volume of about $3400 \mathrm{~m}^{3}$ of sediment was removed leaving $970 \mathrm{~m}^{3}$ of in-situ sediment in the back of the cave (Fernández-Jalvo et al. 2010, Lioubine 2002). Ten stratigraphic horizons were initially defined by Guseinov (Guseinov 1985, Lioubine 2002, Murray et al. 2010). Their excavation produced large samples of lithic artefacts and animal bones, which are currently kept in the Natural History Museum of Baku. A fragment of hominin mandible was discovered in 1968 from Layer $\mathrm{V}$ in the middle of the sedimentary sequence. Age estimates for this specimen vary from 250,000 ka (Guseinov, 1973 cited in Kasimova, 2001, p. 44) to 350,000 - 400,000 ka (Guseinov 1985, cited in Kasimova 2001, p. 44, Hadjiev 1974). The Azokh mandible was named "Palaeoanthropus azykhensis" by Kasimova $(1986,2001)$ who found that this specimen shows a mosaic of archaic and derived features. Kasimova's research suggests that the Azokh mandible is most similar to the Erhingsdorf (adult) specimen, which might now be considered to be early Neanderthal. A recent study by King et al. (in press) also found that the Azokh specimen displays a combination of primitive and derived characters, suggesting that in this regard the Azokh mandibular fragment is similar to older European Pleistocene specimens such as those from Mauer (Germany), Arago (France) and Atapuerca-SH (Spain). King et al. (in press) tentatively assign the Azokh specimen to Homo heidelbergensis. The excavations were interrupted by the Nagorno Karabagh conflict in 1988, but an armistice proposed in 1994 has held to this day.

Current excavations, which began in 2002 through the collaboration of an international, multidisciplinary research team, have focused primarily on the undisturbed, complete sequence of deposits in the upper levels (Units I - V). The systematic recovery and detailed recording of material, and application of new methodologies of the current excavations provide invaluable information on site formation, human behaviour and evolution.

\subsection{Site geology and stratigraphy}

Azokh Cave is a large karstic system situated in the Ishkhanaget river valley. Its host bedrock is a thickly bedded Mesozoic limestone which is considered by Lioubine to be the part of the Jurassic calcareous massif (Murray et al. 2010). The cave has several chambers, the largest of which is Azokh 1; two others, Azokh 2 and Azokh 5 (Figure 2), were discovered during recent detailed survey and mapping work. Current geological work has focused on exploring the cave system and identifying Guseinov's stratigraphy in Azokh 1. Nine stratigraphic units have been determined (Figure 3) which can be divided between two sequences that are no longer physically connected: a lower, older, non-archaeological sequence (Units IX - VI) (Figure 3a), and upper archaeological sequence (Units V -I) (Figure 3c) (Murray et al. 2010, Murray et al. in press) dated between $293 \mathrm{Kyr}-100 \mathrm{Kyr}$ (FernándezJalvo etal. in press). Present excavations have focused on undisturbed levels of the upper sequence. 


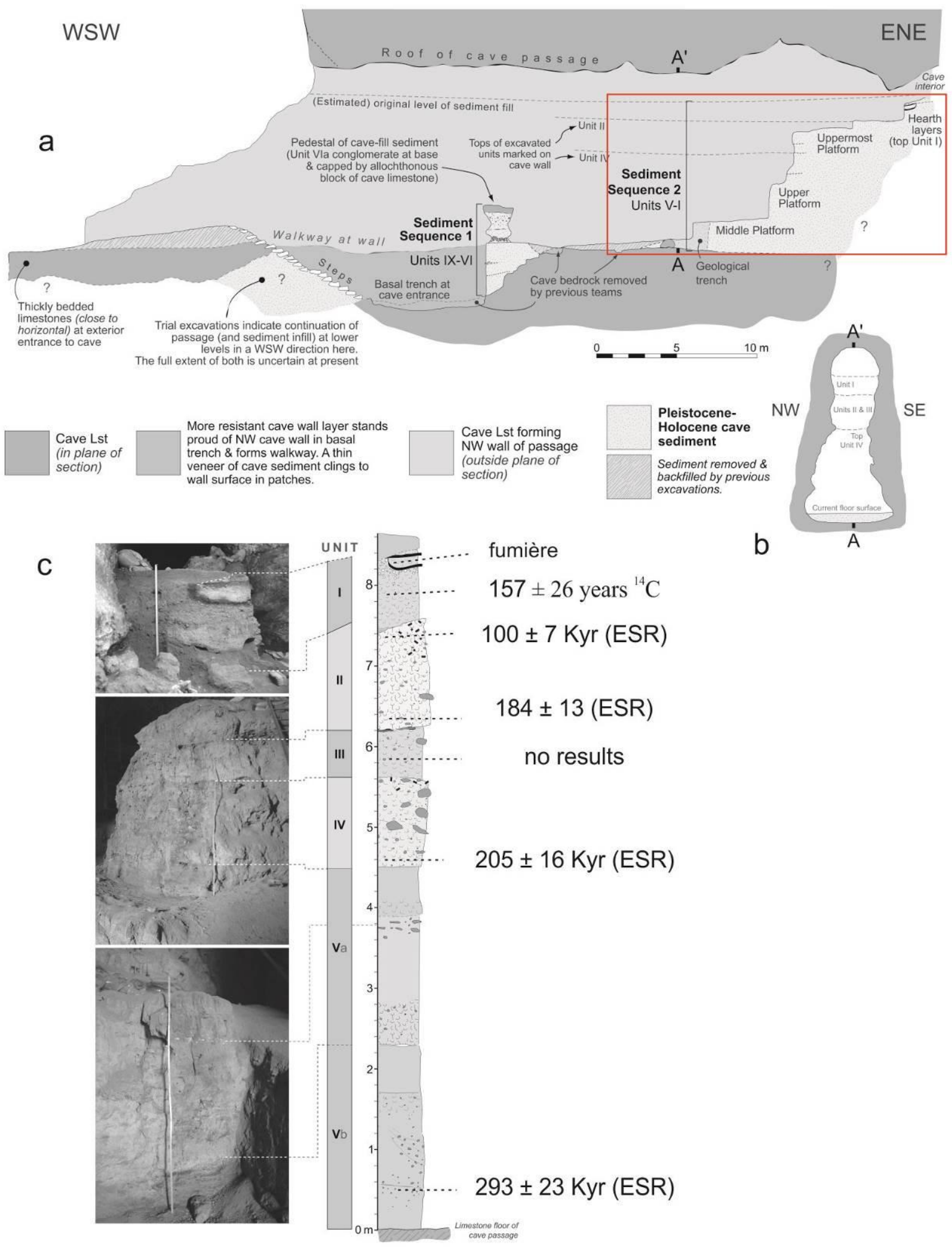

Figure 3. Stratigraphy of Azokh 1: a) Cross section through the entrance passage (facing NW) showing the extent of the cave sediments remaining in the chamber. These are physically separated and are labelled Sediment Sequences 1 and 2. Sequence 2 (inside the rectangle) includes Units I to V. b) Cross section (orthogonal to the section shown in (a)) of Azokh 1 showing the keyhole shape of the passage; c) Stratigraphy of Sediment Sequence 2 with dating results for selected horizons (adapted from Murray et al. 2010, Murray et al. in press). 


\subsection{Non-lithic archaeological finds}

In addition to the lithic assemblages discussed in this paper, Azokh Cave has yielded a large and diverse fauna. Ursus spelaeus and a great range of bats are the most abundant macro- and micro - mammals (Fernández - Jalvo et al. 2010, van der Made in press, Sevilla in press). A variety of cervids and bovids (Cervus elaphus, Dama, Capra aegagrus) as well as tortoise, lagomorphs, rodents, reptiles, and amphibians are present in all excavated units (Fernández - Jalvo et al. 2010, van der Made in press). Large felids (Panthera pardus), canids (Canis lupus, Vulpes vulpes), and bison are present in Unit II. Unit V is characterised by the presence of rhino (Stephanorhinus), badger, wolf, jackal, hyena (Crocuta crocuta), Megaloceros, and roe deer. Wild pigs (Sus scrofa) have been identified in different units (Fernández-Jalvo et al. ibid, van der Made in press). Faunal remains recovered from Unit III and from the upper part of Unit $\mathrm{V}$ consist mainly of low meat and low marrow-bearing elements, including fibulae, hand and foot bones. Many bones are complete and some show cut-marks (Fernández - Jalvo et al. ibid, Marín Monfort et al. in press). Unit II, contains large, marrow-rich limb bones of bear. Some of these bones show signs of human activity (i.e. carcass selection, skin removal and butchery), although the presence of large unbroken bones is also evident (Marín Monfort et al. in press). Preliminary analysis suggests that there is no major spatial separation between bear bones, stone artefacts and other archaeological and palaeontological finds in this unit. In contrast, the small number of remains in Unit V makes it difficult to assess the relationship between bear and herbivore bones and lithic artefacts.

No hearths or other constructed features were identified during the excavations, although many dispersed charcoals are present in all units (Allué in press) and a few artefacts show traces of burning. Phytolith and pollen analyses are currently in progress.

\section{Materials and methods}

The lithic artefacts described here are from the 2002 to 2009 excavations recovered from Units V, III and II of the upper sedimentary sequence of Azokh 1 Cave (Asryan et al. in press). The study sample consists of 387 artefacts: cores, retouched and unretouched flakes, flake fragments and fragments, some of which may be considered as debris. The major part of the combined assemblage ( 315 pieces) is from the upper layer (Unit II), retrieved during open area excavations in 2003, 2005, 2006, 2007, 2008 and 2009, and from an area of $40 \mathrm{~m}^{2}$; a further 68 pieces come from the lower Unit V, recovered from open area excavations of $25 \mathrm{~m}^{2}$ in 2002, 2003, and 2005, and $40 \mathrm{~m}^{2}$ in 2009 . This relatively low concentration of artefacts is due to the location of the current excavation at the back of the cave, about $40-50 \mathrm{~m}$ from the entrance, where there is almost no penetration of natural light. Four pieces were recovered from an initial test-trench exploration of Unit III. Although a morpho-technical analysis of the lithics from Unit III was undertaken, the results and interpretation are not included in the final discussion of this study because there were so few pieces. As the sediment of Unit I was extensively disturbed by recent and ancient animal burrows, the seven pieces recovered from this unit have also been excluded from the present discussion too.

The Logical Analytical System (LAS) (Carbonell et al. 1992, Carbonell \& Rodríguez 1994, Rodríguez 2004) and aspects established by Anglo-Saxon (Clark 2001) and French schools form the theoretical and methodological framework of lithic analysis, used in this study. While LAS serves mainly as a methodological guide for morpho-technical analysis, Clark's work is used to clarify definitions of structural categories and for terminology. Bordes' and Laplace's criteria aid in establishing different types of retouched pieces (Bordes 1961, Laplace 1972). In addition, methodological approaches developed by other authors have been used to analyse Levallois pieces (Baena et al. 2003; Boëda 1994, 2005, van Peer 1992, 1995, Mourre 2003, Terrades 2003, Vaquero \& Carbonell, 2003). 
Prior to analysis each artefact was individually cleaned using 2\% "Derquim" $($ bath (neutral phosphate-free detergent) and subjected to ultrasound cleaning for 10 to 20 minutes. A general, macroscopic analysis of raw material was also undertaken for which a data sheet was created. It includes such variables as raw material colour, texture, patination, raw material structure, impurities and fossils, cortex structure and type, raw material rolling, and type of outcrop. Some specific aspects (i.e. presence of fossils, impurities) were analysed using a reflected light optical microscope (Olympus BH-2).

\section{Results}

\subsection{Raw materials}

A diversity of raw materials is evident in the combined assemblages, although chert, flint and basalt are the most commonly exploited $(60.2 \%, 18.3 \%$ and $13 \%$ respectively). Pieces in obsidian form $3.4 \%$ of the sample. Limestone, jasper, sandstone and agate are also present in small quantities in both units (Table 1).

Table 1. Raw materials present in Units V, III and II (percentages not given for Unit III due to the small number of pieces recovered)

\begin{tabular}{lccccc}
\hline $\begin{array}{l}\text { Raw } \\
\text { material }\end{array}$ & $\begin{array}{c}\text { Unit V No. } \\
\text { present }\end{array}$ & $\begin{array}{c}\text { Unit V \% of } \\
\text { total }\end{array}$ & $\begin{array}{c}\text { Unit III No. } \\
\text { present }\end{array}$ & $\begin{array}{c}\text { Unit II No. } \\
\text { present }\end{array}$ & $\begin{array}{c}\text { Unit II \% of } \\
\text { total }\end{array}$ \\
\hline Chert & 40 & 58.8 & 3 & 190 & 60.3 \\
Flint & 6 & 8.8 & -- & 65 & 20.6 \\
Basalt & 17 & 25 & -- & 36 & 11.4 \\
Obsidian & 3 & 4.4 & 1 & 9 & 2.9 \\
Limestone & 1 & 1.5 & -- & 5 & 1.6 \\
Jasper & -- & -- & -- & 5 & 1.6 \\
Sandstone & -- & -- & -- & 4 & 1.3 \\
Agate & 1 & 1.5 & -- & 1 & 0.3 \\
\hline Total & $\mathbf{6 8}$ & $\mathbf{1 0 0}$ & $\mathbf{4}$ & $\mathbf{3 1 5}$ & $\mathbf{1 0 0}$ \\
\hline
\end{tabular}

The chert used at Azokh, which originates from the karstic system of the cave itself, is mainly grey, and of poor quality with impurities. Six different types of flint have been identified according to colour and are mainly fine-grained, opaque, and have inclusions such as microfossils and lithoclasts. Macroscopically, basalt appears less varied than flint; generally the basalt is dense, fine textured and opaque. The obsidian used by the Azokh Cave toolmakers is mainly black, shiny and translucent, but grey and greenish pieces are also found. All raw materials used in Azokh 1 show conchoidal fracture, although basalt tends to show a slightly irregular fracture. Cortex, present on a few pieces, is calcareous, siliceous and fluvial with no signs or different degrees of rolling which suggests that raw material capture was from primary as well as secondary deposits. Most lithic artefacts on volcanic materials (basalt) show evidence of chemical weathering, which may be related to the highly acidic bat guano present in the soil, especially in Unit II. Study of the effects of bat guano on different raw materials is currently ongoing.

\subsection{Unit $\mathrm{V}$ lithic assemblage}

The small lithic assemblage (68 pieces) recovered from Unit V consists mainly of flake fragments $(51.5 \%)$, some retouched flakes $(10.3 \%)$ and simple flakes $(16.2 \%)$, a few cores 
(4.4\%) and non-diagnostic fragments (17.6\%). The assemblage is mainly of chert (58.8\%) and basalt $(22.1 \%)$ (Table 2).

Table 2. Lithic assemblages of Unit V and Unit II

\begin{tabular}{lcccc}
\hline & \multicolumn{2}{c}{ Unit V assemblage } & \multicolumn{2}{c}{ Unit II assemblage } \\
\hline Category & No. present & $\mathbf{\%}$ & No. present & \% \\
\hline Manuport & -- & -- & 3 & 0.9 \\
Core & 3 & 4.4 & 8 & 2.5 \\
Unretouched flake & 11 & 16.2 & 51 & 16.2 \\
Retouched flake & 7 & 10.3 & 11 & 3.5 \\
Broken flake (with platform and bulb) & 8 & 11.8 & 57 & 18.1 \\
Flake fragment (having distal or lateral & 27 & 39.7 & 126 & 40 \\
$\quad$ segments but no platform or bulb) & & & & \\
Fragment & 12 & 17.6 & 59 & 18.7 \\
\hline Total & $\mathbf{6 8}$ & $\mathbf{1 0 0}$ & $\mathbf{3 1 5}$ & $\mathbf{1 0 0}$ \\
\hline
\end{tabular}

Three cores of basalt, chert and flint, form a small component of the assemblage. They show no systematic pattern of exploitation and have a modal length between 5 and $7 \mathrm{~cm}$ (Table 3). Natural striking platforms are used for unifacial and bifacial removals but no facial hierarchy is evident. Two cores (basalt and flint) are at a medium stage of exploitation and one (chert) is at a final stage. Given the few cores, it is difficult to reconstruct knapping methods, but there is no evidence for the use of the Levallois method.

Table 3. Maximum, minimum and average dimensions of cores and flakes in Unit V and Unit II assemblages.

\begin{tabular}{lcccc}
\hline & Unit V & Unit II & \\
\hline Dimensions & $\begin{array}{c}\text { Cores } \\
(\mathbf{n = 3})\end{array}$ & $\begin{array}{c}\text { Whole flakes } \\
(\mathbf{n = 1 8})\end{array}$ & $\begin{array}{c}\text { Cores } \\
(\mathbf{n = 8})\end{array}$ & $\begin{array}{c}\text { Whole flakes } \\
(\mathbf{n = 6 2})\end{array}$ \\
\hline Length $(\mathrm{mm})$ & & & & \\
max & 75 & 102 & 65 & 90 \\
min & 48 & 31 & 44 & 18 \\
average & 62 & 52.87 & 50.25 & 49.71 \\
\hline Width $(\mathrm{mm})$ & & & & \\
max & 65 & 85 & 56 & 63 \\
min & 30 & 12 & 33 & 9 \\
average & 50 & 39.5 & 45.5 & 32.08 \\
\hline Thickness $(\mathrm{mm})$ & & & & \\
max & 45 & 28 & 30 & 1 \\
min & 21 & 4 & 13 & 7.81 \\
average & 31 & 13 & 22.37 & \\
\hline
\end{tabular}

Unretouched and retouched flakes form $26.5 \%$ of the assemblage from Unit V. They are mainly non-cortical (71.2\%), and average between $4-10 \mathrm{~cm}$ in length (Table 3 and Figure 4). 

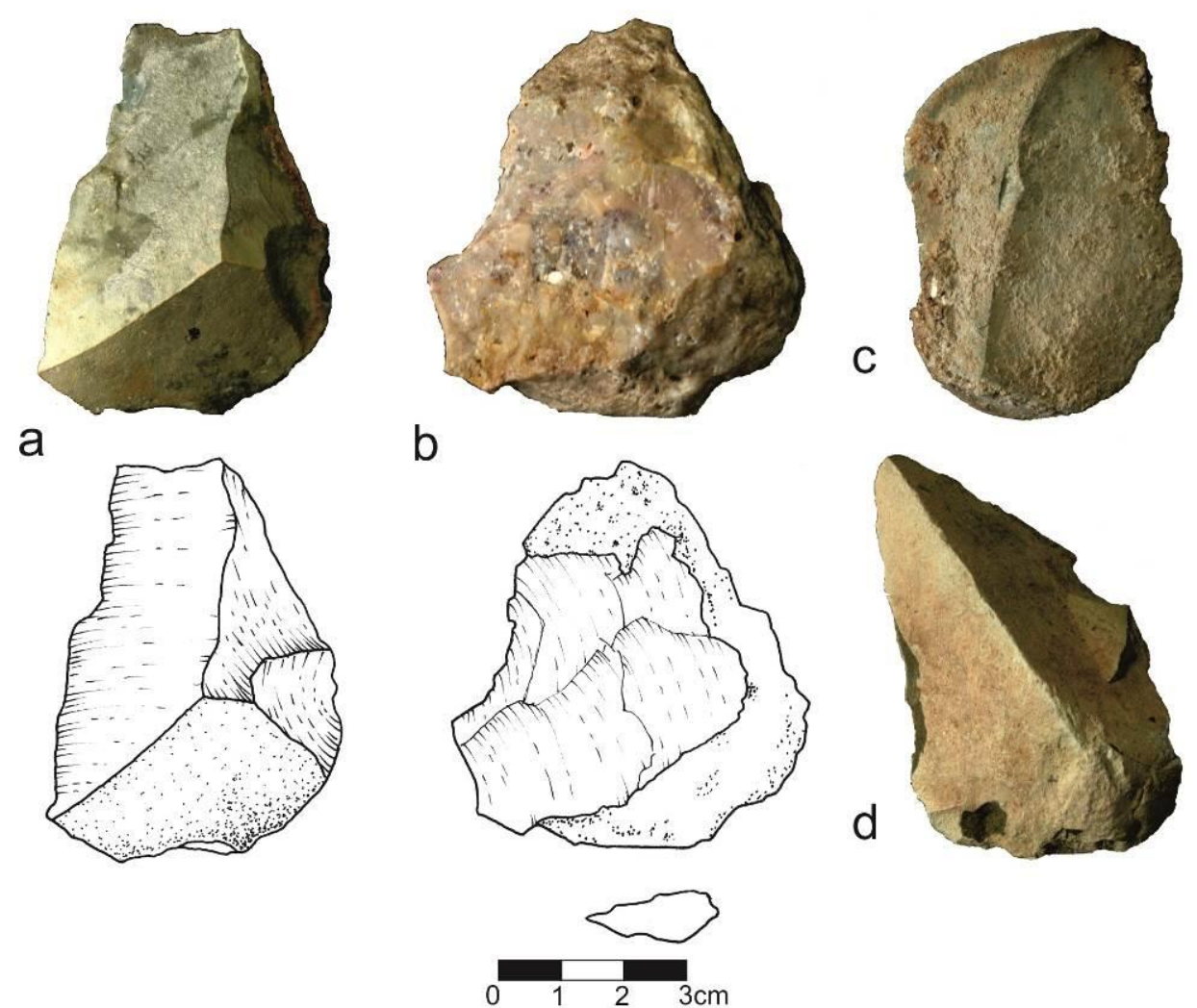

Figure 4. Unit V unretouched flakes: a) (Az1'03 un V, D42 - 14), c) (Az1'03 un V, G42 - 2), and d) (Az1'09 un $\mathrm{V}, \mathrm{H} 41$ - 27) basalt; and b) (Azl'03 un V, F41 - 11) flint (drawings by J. Vilalta).

Most flakes have non-cortical and unifaceted striking platforms. While morphologies may vary, trapezoidal and triangular forms are the most common. Dorsal faces generally have two to three removals that tend to be unidirectional or bidirectional, and, in a few cases, radial. Seven pieces, four flint, two basalt and one obsidian, are modified by retouch that is mainly direct, partial and marginal along one or two edges at a simple and semi-abrupt angle. The obsidian and basalt pieces have intensive, continuous retouch. Typologically, retouched tools are mainly simple side-scrapers and a point (Figure 5).
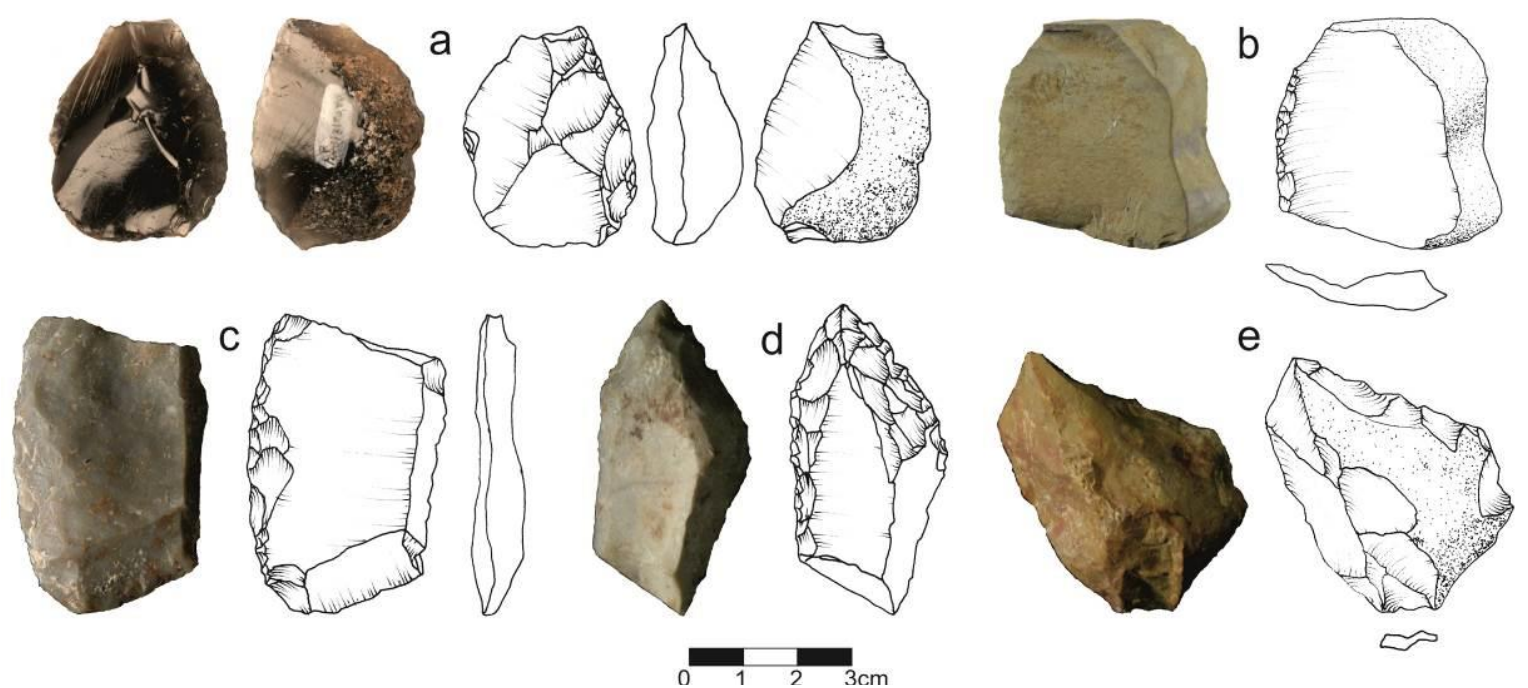

Figure 5. Unit V retouched flakes: a) (Azl'03 un V, F42 - 3) obsidian side-scraper, b) (Az1'02 un V, G39 - 1) basalt side-scraper, c) (Az1'09 un V, F40 - 2) and e) (Az1'09 un V, H41 - 10) flint side-scrapers; and d) (Az1'09 un V, I42 - 42) flint point (drawings by J. Vilalta). 
Fragments vary in size $(1-4 \mathrm{~cm})$, but none show clear evidence (butt, bulb, dorsal and ventral faces) of knapping debris. A refit of three cortical, basalt flakes was found in this unit, the largest of which measures $5 \mathrm{~cm}$, is totally cortical on its dorsal face, and has lateral and proximal fractures. The other two pieces are smaller $(2-3 \mathrm{~cm})$, with partial cortex and multiple fractures.

\subsection{Unit III lithic assemblage}

The assemblage of Unit III consists of three chert flake fragments, and a broken obsidian flake. All pieces have dorsal removals. One piece is modified by an inverse, profound retouch on its left lateral. The obsidian fragment is the only piece which retains a striking platform (unifaceted). Lateral fractures on two pieces indicate post-depositional surface modifications.

\subsection{Unit II lithic assemblage}

The Unit II lithic assemblage totals 315 pieces recovered from an area of $40 \mathrm{~m}^{2}$. It is primarily on siliceous raw materials (chert and flint), although there is a large range of raw materials in this Unit (Table 1). The assemblage is characterised by a high presence of flake fragments $(58.1 \%)$, unretouched $(16.2 \%)$ and retouched $(3.5 \%)$ flakes, a small number of cores $(2.5 \%)$, some knapping debris $(1.3 \%)$, non-diagnostic fragments $(17.5 \%)$, and three manuports $(0.9 \%$ ) (Table 2). Levallois technology is well represented forming $27.6 \%$ of the assemblage (Table 4).

Table 4. Levallois component of Unit II for each technological category.

\begin{tabular}{lcc}
\hline Category & No. present & $\begin{array}{c}\text { \% of Levallois pieces in } \\
\text { each category }\end{array}$ \\
\hline Levallois core & 5 & 62.5 \\
$\begin{array}{l}\text { Levallois flake } \\
\quad \text { (whole and broken flakes and flake fragments) }\end{array}$ & 75 & 32.1 \\
$\begin{array}{l}\text { Retouched Levallois flakes } \\
\text { Total Levallois }\end{array}$ & 7 & 63.6 \\
\hline
\end{tabular}

Manuports are of basalt and vary in size between 3 and $5 \mathrm{~cm}$. Because of their rounded and polished condition we suggest that these pieces may have been transported from the nearby Ishkhanaget river. Their small size and the absence of percussion marks rule out their use as hammer-stones, although they could have been used for retouching or reshaping.

The eight cores (two chert, three flint, three basalt) in Unit II are primarily predetermined and at final stage of exploitation. They range in length from 4.5-6.5 cm (Table 3). Five are Levallois and three are simple. Most are bifacial with clear facial hierarchy. Levallois cores tend to have opposing bipolar extractions but one has unipolar longitudinal extractions. Centripetal working is also evident. Two Levallois cores have preferential removals (Figure 6). Most simple cores indicate either unipolar longitudinal or bipolar orthogonal removals, and show no evidence of prior preparation of extractions. The lack of refits prevents us from reconstructing these reduction sequences more precisely. 


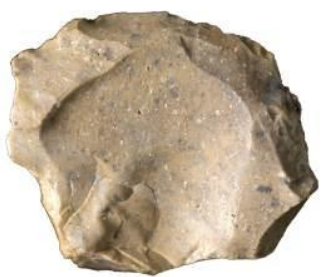

a
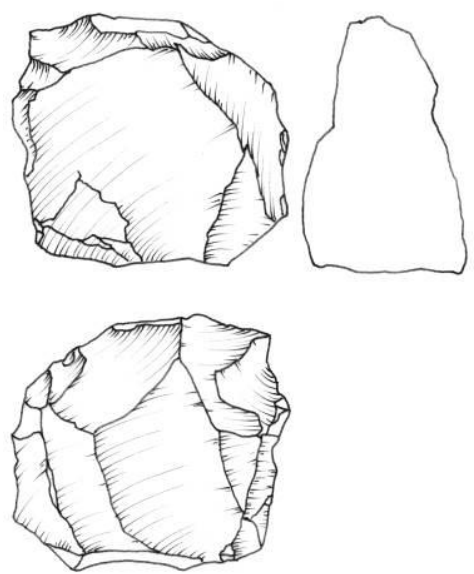

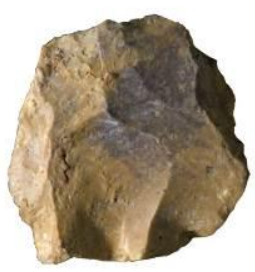

$\mathrm{b}$
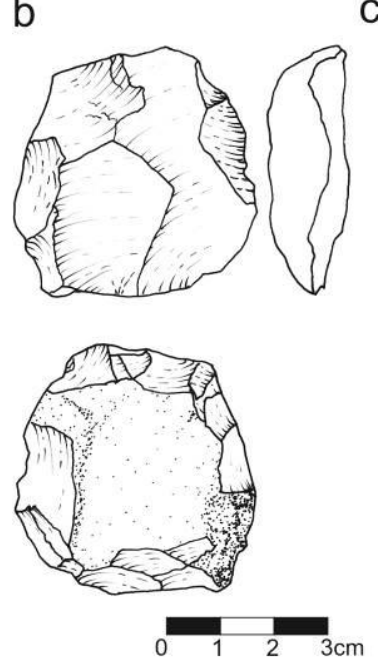

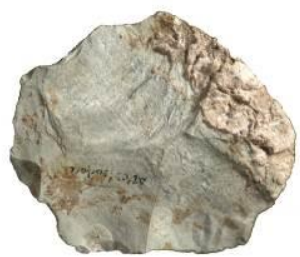

C

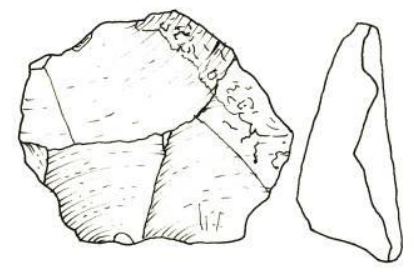

d
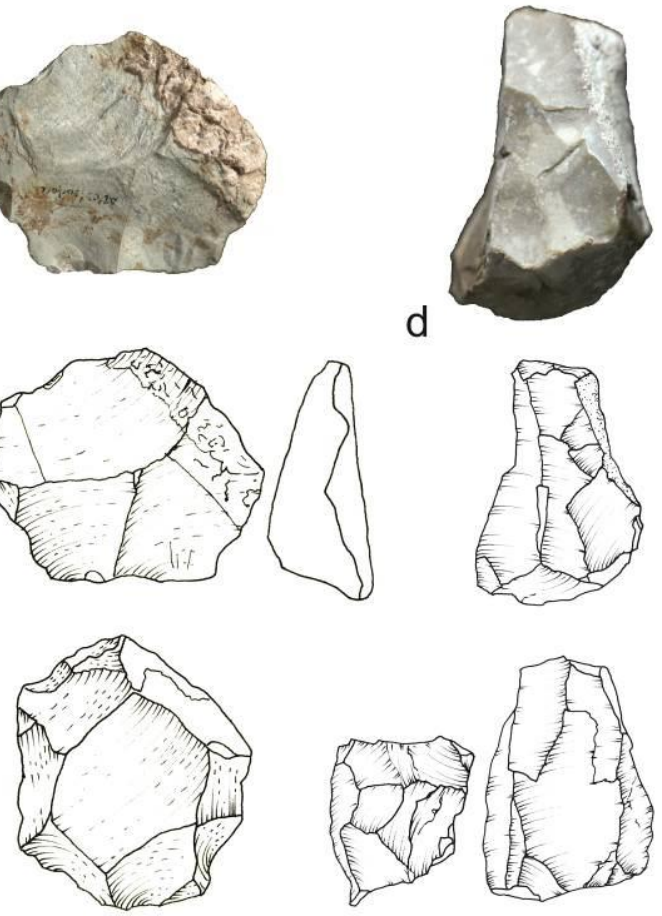

Figure 6. Unit II cores: a) (Az1'05 un II, G47 - 3) and b) (Az1'06 un II, F48 - 139) flint Levallois cores; c) (Az1'03 un II, D46 - 15) basalt Levallois core; and d) (Az1'05 un II, E48 - 4) flint non-Levallois core (drawings by J. Vilalta).

Flake size varies between 2 and $7 \mathrm{~cm}$ (Table 3). Levallois flakes form $32.9 \%$ of the flake assemblage. There is clear evidence for the use of good quality raw materials (flint, basalt, obsidian, jasper and sandstone) for Levallois artefacts and retouched pieces. Although flake morphologies vary, they are mainly trapezoidal and triangular. Platform preparation is evident with a dominance of multifaceted and bifaceted types (75.4\%). Flakes show radial, bidirectional and, at times, also unidirectional dorsal removals (Figure 7).

Retouch, present on $3.4 \%$ of flakes, is usually direct, marginal to profound and continuous along one edge at an abrupt or semi-abrupt angle. The only examples with intensive and stepped retouch are two obsidian pieces. Typologically, simple side-scrapers dominate, although two end-scrapers are also present (Figure 8). It is important to emphasise the high presence of pseudo-retouched pieces (i.e. removals caused by post-depositional processes that mimic deliberate retouch) in this assemblage.

Although a few Unit II fragments $(\mathrm{N}=4)$ are knapping debris, most fragments are shapeless and without clear indication of being knapping waste.

\section{Discussion}

The stratigraphic sequence at Azokh Cave presents one of the most complete and possibly one of the oldest sequences in Nagorno Karabagh. Furthermore, it provides a perspective on human technical capability and behaviour in the Lesser Caucasus during the Middle Pleistocene. This study has focused on the lithic assemblages of two Units (V and II) which are different chronologically, technologically and culturally. Although it is not possible to compare these particular assemblages with each other, we can, nevertheless, emphasise the homogeneity of raw materials, scarcity of knapping debris and cores, and dominance of flakes in both units. However, we can attempt comparisons with materials 
retrieved from earlier excavations at Azokh Cave, and consider their position in micro and macro regional contexts.

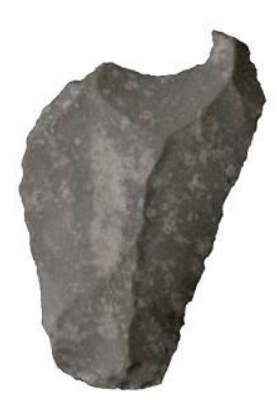

a

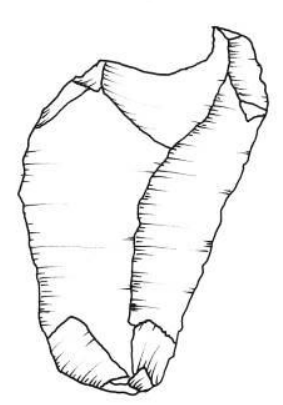

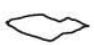

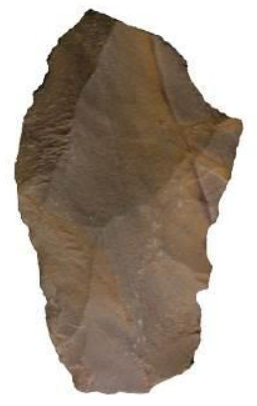

$\mathrm{b}$
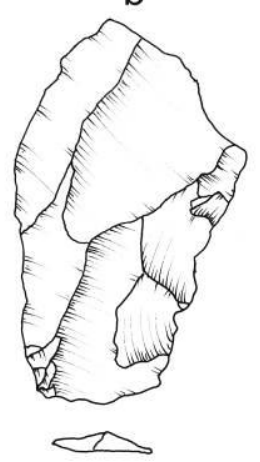

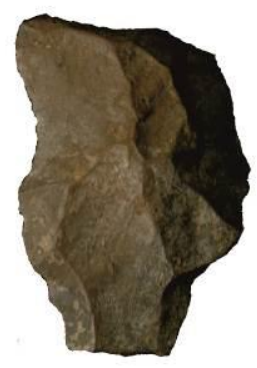

C
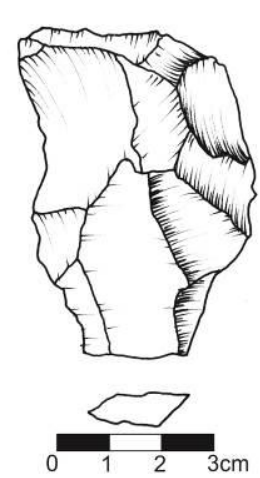

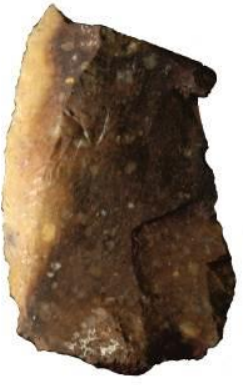

d
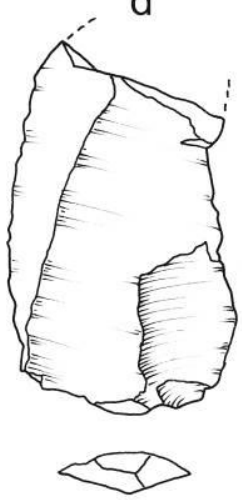

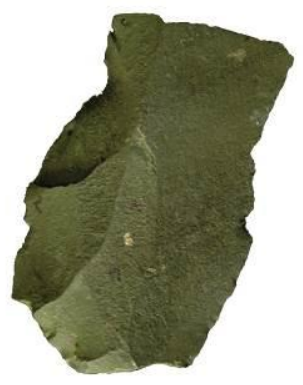

e
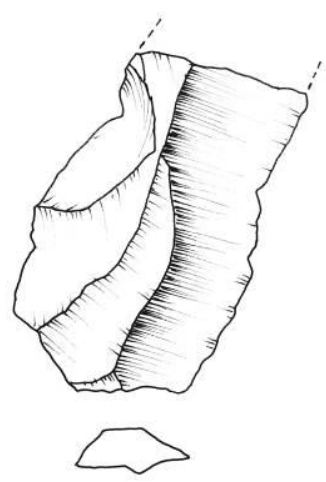

Figure 7. Unit II flakes: a) (Az1'08 un II, C50 - 9), c) (Az1'08 un II, H50 - 2) and d) (Az1'06 un II, G47 - 15) flint Levallois flakes; b) (Azl'05 un II, E48 - 17) sandstone Levallois flake; and e) (Az1'08 un II, C46 - 41) basalt Levallois flake (drawings by J. Vilalta).
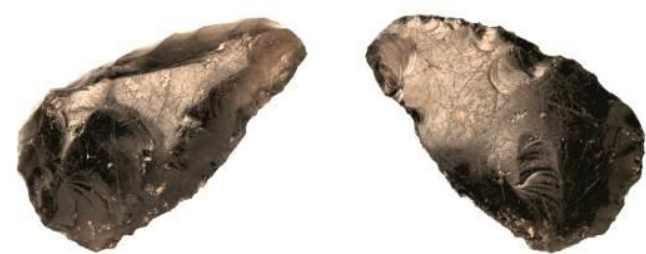

a

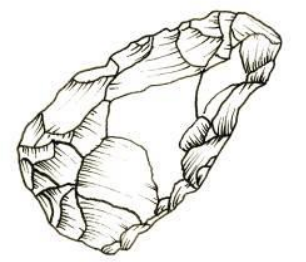

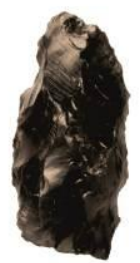

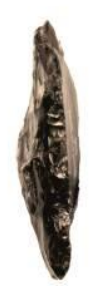

b
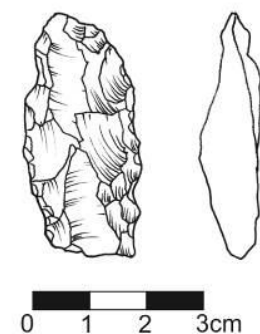
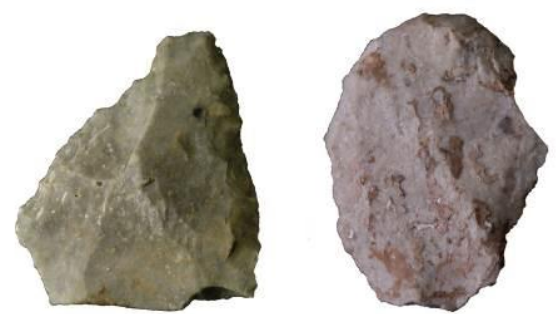

C
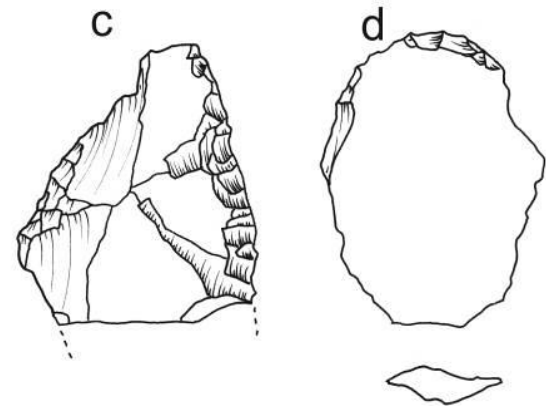

Figure 8. Unit II retouched flakes: a) (Az1'08 un II, D46 - 27) and b) (Az1'03 un II, D46 - 141) obsidian double side-scrapers; c) (Az1'09 un II, E47 - 14) flint side-scraper; and d) (Az1'07 un II, D51 - 49) flint end-scraper (drawings by J. Vilalta). 


\subsection{Raw material economy}

Raw material procurement is generally considered to be an important part of early hominin subsistence strategies (Binford 1979, Féblot-Augustins 1999, Geneste 1985, Rensink 1991, Roebroeks and Tuffreau 1999). As procurement strategies can be on a regional or macroregional scale (Roebroeks and Tuffreau 1999), they indicate early hominin mobility. Correlation of behavioural and technological perspectives (Geneste 1985) may indicate not only the distances and quantities of raw materials transported but also technological stages (i.e. nodules, blocks, exploited cores, flakes) at the time these materials were introduced onto the site. For the Azokh assemblages, this could be the final stage of exploitation.

The lithic assemblages from both units are made on a range of raw materials, although more varied in Unit II. Chert, flint and basalt were most commonly exploited in both units due, probably, to the easy accessibility of these raw materials. While flint and chert appear to have been preferentially exploited for flake tool production in both units, toolmakers show a preference for the "best" raw material (flint, basalt, obsidian, sandstone) for retouched pieces in Units V and II, and for Levallois production in Unit II.

Currently, the lack of regional geological maps prevents determination of the original sources of most raw materials. However, raw material sources may differ according to whether they are sedimentary, metamorphic or volcanic. Chert, flint and some of the volcanic rocks, such as basalt, seem to come from local sources, i.e. the cave area, Azokh village, and the Ishkhanaget river valley located $2-3 \mathrm{~km}$ from the cave. Jasper, sandstone, some types of flint and agate outcrops may be more distant and possibly available as secondary deposits in the Ishkhanaget river. The round, smooth texture of cortex on some artefacts supports this hypothesis.

The only raw material originating from further away is obsidian. There is one known source of obsidian in Nagorno Karabakh located in Mt. Kelbadjar and Kechaldag/Merkasar in the Shahumyan region (Blackman et al. 1998). However, numerous obsidian sources are known in Armenia (Figure 1) and have been classed into three groups by Barge and Chatainger 2003: 1) the Arteni, Gutanasar and Atis volcanic complex located in northern Armenia; 2) the Tsakhkuniats (Damlik, Kamakar) and Ashots ranges in northern Armenia; 3) the Gegham mountains (Geghasar, Spitakasar) and the Syunik range (Sevakar, Satanakar) in southern Armenia. The obsidian at Azokh may originate from the Syunik in the Zangezur mountain range and Mt. Kelbadjar and Kechaldagh/Merkasar in Nagorno Karabagh. Both sources are situated more than $80 \mathrm{~km}$ from Azokh, and are potentially the closest known sources of obsidian to Azokh.

\subsection{Micro and macro regional contexts}

In an attempt to understand more fully the micro and macro contexts of the Azokh assemblages from recent excavations, the following discussion will consider each unit separately.

\subsubsection{Unit V}

Unit V forms the earliest phase of occupation studied in the current excavations at Azokh cave. The artefacts include a relatively high presence of flakes, a low percentage of cores and retouched pieces, but no manuports or large tools (bifaces, choppers, chopping-tools). Fragments are undiagnostic and cannot be considered as knapping waste. The few cores and the only refit of three pieces may be indicative of very limited on-site activities. However, there is no complete operational chain evident in this unit, and no variety in technological (i.e. 
presence of a technical mode or particular knapping tendencies) and economic behaviour (i.e. raw material selectivity, re-use of tools (cores, flakes etc.).

We consulted published information on the lithic assemblages recovered from earlier excavations (Djafarov 1983, Doronichev 2008, Guseinov 1985, Lioubin 2002) in order to allow comparison with the assemblages discussed here. During these excavations, 289 pieces were recovered from Unit V (termed layer V) from an area $\sim 200 \mathrm{~m}^{2}$. In contrast, the current excavations concentrated on deposits remaining $\left(\sim 40 \mathrm{~m}^{2}\right)$ at the back of the cave from which 68 pieces were recovered. Similar to our results, the previous assemblage is characterised by a dominance of flakes, paucity of cores and dominance of side-scrapers among retouched pieces. A major difference between both assemblages is the presence $(6.6 \%)$ of macro-tools (bifaces, choppers, and chopping tools) in the assemblage from the earlier excavations and their absence in the assemblage discussed here. However, the current Unit V is quite thick (c. $4.5 \mathrm{~m}$ ) and excavations are ongoing.

In the Caucasian context, the small assemblage in Unit V makes it difficult to establish any real comparisons with other sites in this region. However, based on particular technotypological characteristics and on dating results, we present some parallels. With a chronological age of $\sim 300 \mathrm{kyr}$, the Unit V assemblage might be considered as Acheulean. Doronichev (2001, 2008) and colleagues (Doronichev et al. 2004, 2007) suggest a late appearance of the Acheulean techno-complex in the Caucasus in comparison to Western Asia, giving an age no older than $350 \mathrm{kyr}$ for the earliest Acheulean industries in the Southern Caucasus. Furthermore, they highlight the limited distribution of the Acheulean technocomplex in the Lesser Caucasus and Central Southern Caucasus. In the Southern Caucasus two Acheulean variants have been identified on technological and typological grounds. The first, termed Kudarian (from Acheulean assemblages at the cave sites of Kudaro I and III, and Tsona) (Figure 1), is characterised by the use of siliceous rocks, rare Acheulean bifaces and absence of Levallois technology. The second variant is characterised by the use of volcanic rocks, presence of numerous Acheulean bifaces, laminar and Levallois debitage (Doronichev 2004, 2008). A study of the stone tool assemblage of Azokh Cave Layer V recovered during the Azerbaijani-Russian excavations, led Doronichev and colleagues (Doronichev 2001, 2008, Doronichev et al. 2004, 2007) to place it within the Kudarian Upper Acheulean variant based on the presence of such characteristics as: knapping technique with parallel flaking from roughly prepared platforms, prevalence of small flake-tools, macro-tools with backed bifaces made on flat pebbles by partial bifacial knapping (known also from Kudaro I), and Acheulean bifaces characterised by the diagnostic Kudarian variant, i.e. a combination of massive amygdaloid or lanceolate bifaces and flat subcordiform bifaces on flakes (Doronichev 2008). The presence of small flake-tools in the Unit V assemblage discussed in this paper is the only characteristic that potentially can be considered as similar to the Kudarian of the previous assemblage. Although the current Unit V assemblage may share similarities with assemblage I of Teugal'naya Cave (Doronichev 2008, Doronichev et al. 2007) or the Lower Palaeolithic assemblage of Kudaro I (Doronichev 2008), its small size and general techno-typological characteristics prevent its allocation to any of those variants or to the Acheulean technocomplex in general. However, it has no chronological or techno-typological parallels with the Mousterian techno-complex.

When trying to draw parallels with the lithic assemblages of the same age in Europe, it is worth considering the presence of "core and flake tool" or Tayacian industries in central and south-central Europe and also the "small tool industries" in central Europe (e.g. Bilzingsleben, Schöningen Vértesszölös (Kuhn \& Stiner 2010). Characteristics of these assemblages, such as a chronology between 300 and $500 \mathrm{Kyr}$ BP, presence of non-Levallois industries with flake-tools, steeply retouched flake tools with irregular edges (Kuhn \& Stiner, 
ibid, Moncel 2003), may have parallels with the Unit V material, but because of the small number of pieces this hypothesis cannot be confirmed as yet.

\subsubsection{Unit II}

The morpho-technical analysis of the Unit II stone tools shows a clear dominance of flakes, with a few cores, retouched pieces, manuports and fragments. Levallois debitage is well represented. The limited numbers of cores, fragments and primary flakes indicate that knapping activities took place outside the excavated zone, possibly in better-lit areas close to the cave entrance (the sediments of which were totally emptied during the previous excavations), outside the cave, or close to the raw material sources. Therefore, it seems likely that most of the lithic artefacts were introduced to the site as end-products.

The Mousterian assemblage from the earlier excavations (Djafarov 1999, Guseinov 1985, Lioubin 2002) was much larger (3039 pieces) than our Unit II assemblage, but the excavation was also much larger. Similarities between both groups include the preferential use of local raw materials, good representation of a Levallois component, dominance of flakes, and few cores. In contrast to our results, knapping debris is well represented (73\% of fragments). One important difference to be noted between both assemblages is the presence of a discoid component in the previous assemblage and its absence in the current one. A further difference is the importance of scrapers, notches and denticulates in the earlier assemblage (Djafarov 1999, Lioubine 2002) and their paucity in the studied assemblage (11 retouched pieces, typologically mainly side-scrapers). However, a very high incidence of pseudo-retouch (i.e. pseudo-notches and pseudo-denticulates) has been noted in the present assemblage which might be related to trampling. Dated between $100-184 \mathrm{Kyr}$, the Unit II assemblage technotypologically clearly corresponds to the Mousterian techno-complex. Golovanova and Doronichev (2003) recognised three Middle Palaeolithic cultural areas in the Caucasus: 1) North Caucasian Micoquian in the North-western Caucasus; 2) Khostinian in the Southcentral Great Caucasus; and 3) Zagros Mousterian in the southernmost part of the Caucasus. Il'skaya 1, Il'skaya 2, and Barankha open-air sites, Monasheskaya, Barakaevskaya, Mezmaiskaya cave sites, and Gubs rock-shelter are recognised Middle Palaeolithic sites with Micoquian industries in the North-Western Caucasus. The main characteristics linking these sites and distinguishing them from other Mousterian sites in the Caucasus are the following: presence of bifacial tools (which include small broad triangular handaxes), laurel leaf-like projectile points, various bifacial and partly bifacial convergent tools, and bifacial sidescrapers or knives. The Kosta or Khostinian group was first recognised by Liubin (1977) as denticulate Mousterian of Levallois facies in six cave-sites (Ashtirskaya, Malaya Vorontsovskaya, Navalishenskaya, Antsinskaya, Khostinskaya I and Khostinskaya II) close to Sochi. Three tool groups are differentiated in these sites: 1) denticulates/notches, most of which have irregular retouch apparently resulting from utilisation and trampling; 2) sidescrapers, the most characteristic being déjeté and convergent, accompanied by rare retouched points; and 3) end-scrapers (Golovanova and Doronichev 2003). The third, the ZagrosMousterian cultural area in the southernmost part of the Caucasus, comprises two technical groups (Golovanova and Doronichev ibid.): a) Taglar type industry, known from Mousterian layers of Taglar Cave (Nagono Karabakh) characterised by simple or double side-scrapers with bidirectional and, less commonly, centripetal, truncated-faceted dorsal faces, called "side-scrapers with thinned body" or "Taglar-type" (Djafarov 1983, p. 53); and b) Yerevan type industry first recognised by Eritsian (1981) as the earliest Mousterian in Armenia, based on his excavations in Yerevan 1 cave. The industry is characterised by moderate values of Levallois flakes, flakes with faceted platforms, low blade indices, and side-scrapers and retouched points, which dominate the tool types. A specific feature of the industry is the wide 
use of various methods of thinning for tool production, including the truncated-faceted technique. Diagnostic tool types, related to the truncated-faceted technique, are retouched triangular points with truncated-faceted bases ("Yerevan-type" points), and side-scrapers with two or three truncated-faceted sides ("side-scraper with thinned body") (Eritsian 1981). Similarities to the Mousterian layers of Taglar and Yerevan are also present in the CI assemblage of Lusakert I cave (Armenia) (Golovanova and Doronichev 2003). Taking into account the characteristics of all three cultural areas in the Caucasus defined by these authors, we think that our Unit II assemblage shares similarities (i.e. good presence of Levallois flakes, flakes with faceted platforms, low blade indices, dominance of side-scrapers within retouched pieces) with the Zagros-Mousterian group, although none of the diagnostic tools ("Taglar type" scrapers or "Yerevan type" points) have been found so far in the current assemblage of this unit. The new data from Hovq 1 cave (Pinhasi et al. 2008, 2011) in Northern Armenia, indicates similarities with our Unit II in age (especially Hovq 1 unit 8 dated to $104 \pm 9.8 \mathrm{BP}$ (Pinhasi et al. 2011) and techno-typological characteristics (i.e. presence of Levallois technology - also in unit 8). Pinhasi et al. (ibid) suggest the Hovq unit 8 assemblage is similar to assemblages in Kudaro I and III, Djruchula Cave in Georgia, and Tsona in South Ossetia (Figure 1) that typologically form the Kudaro-Dhruchula group. This technological group is characterised by a presence of elongated Levallois points, blades and scarcity of cores, debitage and other tool types (Adler \& Tushabramishvili 2005, Meignen \& Tushbramishvili 2006, Pinhasi et al. 2011). It is clear that, at present, the Unit II lithics recovered from recent excavations at Azokh cannot be placed confidently within a particular techno-typological context in the Caucasus. It is hoped that ongoing excavation of the Unit will enlarge the lithic database and help clarify the situation.

\section{Conclusions}

Azokh is a Middle to Late Pleistocene cave site that provides evidence of early human settlement in the Caucasus. Renewed excavations of the site have yielded two technotypologically different lithic assemblages which on a regional scale can be an important source of information about early hominin occupation in this territory and can shed light on the technical, socio-economic and cultural behaviour of Azokh Cave inhabitants. In particular this study shows that:

The lithic assemblages of both Unit V and Unit II are made from a range of raw materials, although more varied in Unit II. Chert, flint and basalt were most commonly exploited in both units due, probably, to the easy accessibility of these raw materials. While flint and chert appear to have been preferentially exploited for flake tool production in both units, toolmakers show a preference for the "best" raw material (flint, basalt, obsidian, sandstone) for retouched pieces in Units V and II, and for Levallois production in Unit II.

Chert, flint and some of the volcanic rocks, such as basalt, seem to come from local sources, i.e. the cave area, Azokh village, and the Ishkhanaget river valley located $2-3 \mathrm{~km}$ from the cave. Jasper, some types of flint, sandstone and agate outcrops may be more distant and possibly available as secondary deposits in the Ishkhanaget River.

Exploitation of non-local material is evident in the presence of obsidian, the nearest known source being more than $80 \mathrm{~km}$ distant from Azokh today. Such a distance may indicate the size of territories exploited by Azokh hominins, scale of mobility, techno-economic behaviour, the manner in which raw material is transported and introduced into the site, its exploitation, use and discard.

Unit $\mathrm{V}$ forms the earliest phase of occupation studied in the current excavations at Azokh cave. Artefacts include a relatively high presence of flakes, a low percentage of cores and retouched pieces, but no manuports or large tools (bifaces, choppers, chopping-tools). 
Fragments are undiagnostic and cannot be considered as knapping waste. There is no complete operational chain evident in this unit, and no variety in technological (i.e. presence of a technical mode or particular knapping tendencies) and economic behaviour (i.e. raw material selectivity, re-use of tools (cores, flakes etc.).

The morpho-technical analysis of the Unit II stone tools shows a clear dominance of flakes, with a few cores, retouched pieces, manuports and fragments. Levallois debitage is well represented. The limited numbers of cores, fragments and primary flakes indicates that knapping activities took place outside the excavated zone, possibly in better-lit areas close to the cave entrance (the sediments of which were totally emptied during the previous excavations), outside the cave, or close to the raw material sources. Therefore, it seems likely that most of the lithic artefacts were introduced to the site as end-products.

While the assemblage from Unit V currently cannot be assigned to a technological Mode (i.e. Mode 2 or Mode 3) or a techno-typological group in the Caucasus (e.g. Kudarian), the assemblage from Unit II is clearly Mode 3 of Mousterian tradition and shares similarities with some techno-typological variants in the Caucasus (e.g. Zagros-Mousterian, KudaroDjruchulian).

\section{Acknowledgments}

We thank the authorities of Nagorno Karabagh for their support and permission to excavate at Azokh Cave and also those institutions and people who have provided funding for the project: the government of the Republic of Nagorno Karabagh, Museo Nacional de Ciencias Naturales (CSIC); Spanish Ministry of Science (BTE2000-1309, BTE2003-01552; BTE2007-66213); AGBU (London Trust); and several anonymous donors, one of whom has provided long-term financial support for the project. L. Asyran is grateful to the grants received from Erasmus Mundus programme of European Commission and Wenner-Gren Foundation (WIF-212). We are grateful to Dr. Melanya Balayan and staff at the Artsakh State Museum of History and Country Study for facilitating the study of Azokh Cave lithic material. Thanks too, to Dr. Marta Arzarello and anonymous reviewer for their comments and Dr. Fernandez-Jalvo and Dr. Murray for their invaluable information on the geology and dates of the site. We thank J. Vilalta for his assistance with lithic illustrations. This paper is based on the results of a Masters thesis by one of us (LA). This work has been developed within the general framework of the Spanish MICINN project CGL2012-38434-C03-03 and the Catalan AGAUR project 2009SGR-188.

\section{References}

Adler, D.S., Yeritsyan, B., Wilkinson, K., Pinhasi, R., Bar-Oz, G., Nahapetyan, S., Mallol, C., Berna, F., Bailey, R., Beverly, A., Glauberman, Ph., Wales, N. \& Gasparyan, B. 2012, The Hrazdan Gorge Palaeolithic project, 2008 - 2009. In: Archaeology of Armenia in regional context Proceedings of the International Conference dedicated to the $50^{\text {th }}$ Anniversary of the Institute of Archaeology and Ethnography 15-17 September, 2009 Yerevan (Avetisyan, P. \& Bobokhyan, A., Eds.), GITUTYUN, Yerevan: p. 7-22.

Adler, D., Bar-Oz, G., Belfer-Cohen, A., Bar-Yosef, O. 2006, Ahead of the game - Middle and Upper Palaeolithic hunting behaviours in the Southern Caucasus. Current Anthropology, 47: 89-118.

Adler, D.S. \& Tushabramishvili, N. 2004, Middle Palaeolithic patterns of settlement and subsistence in the Southern Caucasus. In: Middle Palaeolithic Settlement Dynamics, (Conard, N., Ed.), Kerns Verlag, Tübingen: p. 91-132. 
Allué, E. (in press), Charcoal remains from Azokh 1: Preliminary results. In: Azokh Cave and the Transcaucasian Corridor, Chapter 15, (Fernández-Jalvo, Y., Andrews, P., King, T., \& Yepiskoposyan, L., Eds.), Vertebrate Paleobiology and Paleoanthropology Book Series. Springer, Dordrecht.

Asryan, L., Moloney, N. \& Ollé, A. (in press), Lithic assemblages recovered in Azokh 1. In: Azokh Cave and the Transcaucasian Corridor, Chapter 4, (Fernández-Jalvo, Y., Andrews, P., King, T \& Yepiskoposyan, L., Eds.), Vertebrate Paleobiology and Paleoanthropology Book Series. Springer, Dordrecht.

Baena, J., Carrión, E., Requejo, V. 2003, Recent Discoveries of discoid industries in Western Cantabria (North Spain). In: Discoid Lithic Technology. Advances and Implications, (Peresani, M., Ed.), B.A.R. International Series Vol. 1120, Aechaeopress, Oxford: p. 117-126.

Barge, O. \& Chataigner, C. 2003, The procurement of obsidian: factors influencing the choice of deposits. Journal of Non-Crystalline Solids, 323: 172-179. doi:10.1016/S0022-3093(03)00301-6

Bar-Oz, G., Weissbrod, L., Gasparian, B., Nahapetyan, S., Wilkinson, K. \& Pinhasi, R. 2012, Taphonomy and zooarchaeology of a high-altitude Upper Pleistocene faunal sequence from Hovq-1 Cave, Armenia. Journal of Archaeological Science, 39: 2452-2463. doi: $10.1016 / j . j$ as.2012.02.014

Binford, L.R. 1979, Organization and formation processes: Looking at curated technologies. Journal of Anthropological Research, 35 (3): 255-273.

URL: http://www.jstor.org/stable/3629902

Blackman, J., Badaljan, R., Kikodze, Z., Kohl, Ph. 1998, Chemical characterization of Caucasian obsidian geological sources. In: L'obsidienne au Proche et Moyen Orient. Duvolcan à l'outil, (Cauvin, M-C., Gourgaud, A., Gratuze, B., Arnaud, N., Poupeau, G., Poidevin, J-L. \& Chataigner, C., Eds.), B.A.R. International Series Vol. 738, Archaeopress, Oxford: p. 206-231.

Boëda, E. 2005, Paléo-Technologie ou anthropologie des techniques? Arob@se, 1: 46-64. (in French) ("Paleo-technology or the antrhopology of techniques?")

Boëda, E. 1994, Le concept Levallois: variabilité des méthodes. Monographie du CRA, 9, CNRS Editions, Paris, 280 p. (in French) ("The Levallois concept: variability of methods")

Bordes, F. 1961, Typologie de Paléolithique Ancien et Moyen, Publications de l'Institut de Préhistoire de l'Université de Bordeaux. Mémoire No. 1. Delmas, Bordeaux. 108p. (in French) ("Typology of the Lower and Middle Palaeolithic")

Carbonell, E., Mosquera, M., Ollé, A., Rodríguez, X.P., Sala, R., Vaquero, M., Vergés, J.M. 1992, New elements of the Logical Analytic System. Cahier Noir, 6: 5-61.

Carbonell, E. \& Rodríguez, X.P. 1994, Early Middle Pleistocene deposits and artifacts in the Gran Dolina site (TD-4) of the Sierra de Atapuerca (Burgos, Spain). Journal of Human Evolution, 26: 291-311. doi:10.1006/jhev.1994.1018

Clark D.J. 2001, The Stone Age cultural sequence: terminology, typology and raw material. In: Kalambo Falls Prehistoric site, 3. The Middle and Earlier Stone Age, (Clark, J.D., Ed.) Cambridge University Press, Cambridge: 35-65. 
Djafarov, A. 1999, Средний Палеолит Азербайджана, Elm, Baku, 345 p. (in Russian) ("Middle Palaeolithic of Azerbaijan")

Djafarov, A. 1983, Мустьерская культура Азербайджана (по материалам Тагларской nemepbl), Elm, Baku: 228p. (in Russian) ("The Mousterian Culture of Azerbaijan (based on the material of Taglar Cave")

Doronichev, V.B. 2008, The Lower Palaeolithic in Eastern Europe and the Caucasus: a reappraisal of the data and new approaches. PaleoAnthropology, 2008: 107-157.

Doronichev, V.B. 2001, Первоначальное заселение в Восточной Европы, . Донская археология, 3-4(12-13): 6-23. (in Russian) (“Initial Occupation in Eastern Europe”)

Doronichev, V., Golovanova, L., Baryshnikov, G., Blackwell, B., Garutt, N., Levkovskaya, G., Molodkov, A., Nesemyanov, S., Pospelova, G., Hoffecker, J. 2007, . Пещера Треугольная: Ранний Палеолит на Ковказе и в Восточной Европе. Ostrowityanian, St. Petersburg, 270 p. (in Russian) ("Treugol'naya Cave: The Early Palaeolithic in the Caucasus and Eastern Europe")

Doronichev, V., Blackwell, B., Golovanova, L., Levkovskaya, G., Pospelova, G. 2004, Treugol'naya Cave in the Northern Caucasus, Russia: its chronology, paleoenvironments, industries, and relationship to the Lower Palaeolithic in Eastern Europe. Eurasian Prehistory, 2: 77-100.

Eritsian, В. 1981, Новая нижнепалеолитическая пещерная стоянка Лусакерт 1 (Армения), Kratkie soobsheniya institute archeologii, Yerevan, 141 p. (in Russian) ("A new Lower Palaeolithic cave site of Lusakert I (Armenia)")

Féblot-Augustins, J. 1999, Raw material transport patterns and settlement system in the European Lower and Middle Palaeolithic: continuity and variability. In: Chapter 10: The Middle Palaeolithic Occupations of Europe, (Roebroeks, W. and Gamble, C., Eds.), University of Leiden, Leiden: p. 193 - 214.

Fernández-Jalvo, Y., Ditchfield, P., Grün, R., Lees, W., Aubert, M., Torres, T., Ortiz, J.E., Díaz Bautista, A. and Pickering, R. (in press). Dating methods applied to Azokh Cave sites (Annex). In: Azokh Cave and the Transcaucasian Corridor, (Fernández-Jalvo, Y., Andrews, P., King, T., \& Yepiskoposyan, L., eds.), Vertebrate Paleobiology and Paleoanthropology Book Series. Springer: Dordrecht.

Fernández-Jalvo, Y.; King, T.; Andrews, P., Yepiskoposyan, L., Moloney, N.; Murray, J.; Domínguez-Alonso, P.; Asryan, L.; Ditchfield,P.; van der Made, J.; Torres, T.; Sevilla, P.; Nieto Díaz, M.; Cáceres, I.; Allué, E.; Marín Monfort, M.D.; Sanz Martín, T. 2010, The Azokh Cave complex: Middle Pleistocene to Holocene human occupation in the Caucasus. Journal of Human Evolution, 58: 103-109. doi:10.1016/j.jhevol.2009.07.005

Gabunia, L., Antón, S., Lordkipanidze, D., Vekua, Justus, A. \& Swisher C.C.III. 2001, Dmanisi and dispersal. Evolutionary Anthropology, 10: 158-170. doi: $10.1002 /$ evan.1030

Geneste, J.M. 1985, Analyse d'industries moustériennes du Périgord: une approche technologique du comportement des groupes humains au Paléolithique Moyen, $\mathrm{PhD}$ thesis, Université de Bordeaux I, Bordeaux. (in French) ("Analysis of Middle Palaeolithic industries of Périgord : a technological approach to the behaviour of human groups in the Middle Palaeolithic") 
Golovanova, L., Doronichev, V., Cleghorn, N., Koulkova, M., Sapelko, T., Shackley, M. 2010, Significance of ecological factors in the Middle to Upper Palaeolithic Transition. Current Anthropology, 51: 655-691. doi:10.1086/656185

Golovanova, L. \& Doronichev, V. 2003, The Middle Palaeolithic of the Caucasus. Journal of World Prehistory, 17: 71-140. doi:0892-7537/03/0300-0071/0

Golovanova, L., Hoffecker, J., Kharitonov, V., Romanova G. 1999, Mezmaiskaya Cave: A Neanderthal occupation in the Northern Caucasus. Current Anthropology, 40: 77-86. doi: $10.1086 / 515805$

Ghukasyan, R., Colonge, D., Nahapetyan, S., Ollivier, V., Gasparyan, B., Monchot, H. \& Chatainger, Ch. 2011, Kalavan-2 (North of Lake Sevan, Armenia): A New Late Middle Palaeolithic site in the Lesser Caucasus. Archaeology, Ethnology \& Anthropology of Eurasia, 38: 39-51.

Guseinov, M.M. 1985, Древний Палеолит Азербайджана, Elm, Baku: 96 p. (in Russian) ("Lower Palaeolithic of Azerbaijan")

Kasimova, R.M. 2001. Anthropological research of Azykh Man osseous remains. Human Evolution, 16: 37-44. doi:10.1007/BF02438921

Kasimova, R.M. 1986, Первая находка самого древнего пешерного человека на mерритории CCCP, Elm, Baku: 68 p. (in Russian) ("The first discovery of remains of the oldest cave hominin in the territory of USSR")

King, T., Compton, T., Rosas, A., Andrews, P. Yepiskoposyan, L., and Asryan, L. (in press), Azokh Cave Hominin Remains. In: Azokh Cave and the Transcaucasian Corridor Chapter 5 (Fernández-Jalvo, Y., Andrews, P., King, T., \& Yepiskoposyan, L., Eds.), Vertebrate Paleobiology and Paleoanthropology Book Series. Springer: Dordrecht.

Laplace, G. 1972, La Typologie Analytique et Structurale: Base Rationnelle d'Étude des Industries Lithiques et Osseuses, Banques des données archéologiques. Colloques nationaux du CNRS, 932: 91-143. (in French) ("Analytical and Structural Typology: Rational Basis for the Study of Lithic and Faunal Industries")

Lioubine, V.P. 2002, L'Acheuléen du Caucase, Études et Recherches Archéologiques de l'Université de Liège, ERAUL Vol. 93, Liège: 140 p. (in Fench) ("The Acheulean of the Caucasus")

Liubin, V.P. 1977, Мустьерские культуры Кавказа, Nauka, Leningrad, 223 p. (in Russian) ("Mousterian Cultures of the Caucasus")

van der Made, J., Torres, T., Ortiz, J.E., Moreno-Pérez, L. and Fernández-Jalvo, Y. (in press), The new material of large mammals from Azokh and comments on the older collections. In: Azokh Cave and the Transcaucasian Corridor, Chapter 6 (FernándezJalvo, Y., Andrews, P., King, T., \& Yepiskoposyan, L., Eds.), Vertebrate Paleobiology and Paleoanthropology Book Series. Springer: Dordrecht

Marín-Monfort, M.D., Cáceres, I., Andrews, P. and Fernández-Jalvo, Y. (in press), Taphonomy and site formation of Azokh 1. In: Azokh Cave and the Transcaucasian Corridor, Chapter 10 (Fernández-Jalvo, Y., Andrews, P., King, T., \& Yepiskoposyan, L., Eds.), Vertebrate Paleobiology and Paleoanthropology Book Series. Springer, Dordrecht.

Meignen, L.\&Tushabramishvili, N. 2006, Paléolithique Moyen laminaire sure les flancs sud du Caucase: production lithiques et fonctionnement du site de Djruchula (Georgie). 
Paléorient, 32(2): 81-104. (in French) ("Laminar Middle Palaeolithic on the southern flanks of the Caucasus: lithic production and function at the site of Djruchula (Georgia)")

Mourre, V. 2003. Discoïde ou pas Discoïde? Réflexions sur la pertinence des critères techniques définissant le débitage discoïde. In: Discoid Lithic Technology. Advances and Implications. (Peresani M., Ed.). B.A.R International Series Vol. 1120, Archaeopress, Oxford: p. 54-72. (in Fench) ("Discoidal or non-discoidal? Reflections on the relevance of technical criteria defining discoidal debitage")

Murray, J., Lynch, E.P., Domínguez-Alonso, P. \& Barham, M. (in press), Stratigraphy and Sedimentology of Azokh Caves. In: Azokh Cave and the Transcaucasian Corridor, Chapter 2, (Fernández-Jalvo, Y., Andrews, P., King, T., \& Yepiskoposyan, L., Eds.), Vertebrate Paleobiology and Paleoanthropology Book Series. Springer, Dordrecht.

Murray, J., Domínguez-Alonso, P., Fernández-Jalvo, Y., King, T., Lynch, E.P., Andrews, P., Yepiskoposyan, L., Moloney, N., Cacères, I., Allué, E., Asryan, L., Ditchfield, P. \& Williams, D.M. 2010, Pleistocene to Holocene stratigraphy of Azokh 1 Cave, Lesser Caucasus. Irish Journal of Earth Science, 28: 75-91. doi:10.3318/IJES.2010.28.75

van Peer, P. 1995, Current Issues in the Levallois Problem. In: The Definition and Interpretation of Levallois Technology, (Dibble, H. and Bar-Yosef, O., Eds.), Monographs in World Archaeology Vol. 23, Madison, Wisconsin: p. 1-9.

van Peer, P. 1992, The Levallois Reduction Strategy, Monographs in World Archaeology, Madison, Wisconsin, $137 \mathrm{p}$.

Pinhasi, R., Gasparian, B., Nahapetyan, S., Bar-Oz, G., Weissbrod, L., Bruch, A., Hovsepyan, R., Wilkinson, K. 2011, Middle Palaeolithic human occupation of the high altitude region of Hovq - 1, Armenia. Quaternary Science Reviews, 30: 3846 - 3857. doi:10.1016/j.quascirev.2011.09.020

Pinhasi, R., Gasparian, B., Wilkinson, K., Bailey, R., Bar-Oz, G., Bruch, A., Chataigner, C., Hoffmann, D., Hovsepyan, R., Nahapetyan, S., Pike, A., Schreve, D., Stephens, M. 2008, Hovq 1 and the Middle and Upper Palaeolithic of Armenia: a preliminary framework. Journal of Human Evolution, 55: 803-816. doi:10.1016/j.jhevol.2008.04.005

Rensink, E., Kolen, J., \& Spieksma, A. 1991, Patterns of raw materials distribution in the Upper Pleistocene of Northern and Central Europe. In: Raw Material Economies among Prehistoric Hunter-Gathers (Montet-White, A. and Holen, S., Eds.), Publications in Anthropology Vol. 19, University of Kansas, Lawrence, Kansas: p. 141-159.

Rodríguez, X.P. 2004, Technical systems of lithic production in the Lower and Middle Pleistocene of the Iberian Peninsula. Technological variability between North-Eastern sites and Sierra de Atapuerca sites, B.A.R. International Series Vol. 1323. Archaeopress, Oxford: $184 \mathrm{p}$.

Roebroeks,W. \& Tuffreau, A. 1999, Palaeoenvironment and settlement patterns of the Northwest European Palaeolithic. In: The Middle Palaeolithic Occupations of Europe, (Roebroeks, W. and Gamble, C., Eds.), University of Leiden, Leiden: p. 121 - 138.

Sevilla, P. (in press), Bats from Azokh 1 Cave, preliminary results. In: Azokh Cave and the Transcaucasian Corridor, Chapter 8, (Fernández-Jalvo, Y., Andrews, P., King, T., \& Yepiskoposyan, L., Eds.), Vertebrate Paleobiology and Paleoanthropology Book Series. Springer, Dordrecht. 
Terrades, X. 2003, Discoid Flaking Method: Conception and Technological Variability. In: Discoid Lithic Technology. Advances and Implications, (Peresani, M., Ed.), B.A.R International Series Vol. 1120. Archaeopress, Oxford: p. 1-14.

Vaquero, M. \& Carbonell, E. 2003, A temporal perspective on the variability of the discoid method in the Iberian Peninsula. In: Discoid Lithic Technology. Advances and implications, (Peresani, M., Ed.), B.A.R. International Series Vol. 1120, Archaeopress, Oxford: p. 67-81. 